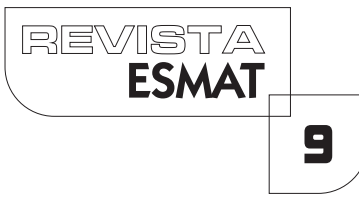

\title{
MARXISMO E HISTÓRIA SOCIAL DOS DIREITOS HUMANOS
}

Charles de Sousa Trigueiro

Aluno do Mestrado em Ciência Jurídicas da UFPB. Bacharel em Ciências Jurídicas e Sociais pela UFPB. Servidor Técnico Administrativo da UFPB.

\section{RESUMO}

$\bigcirc$ presente artigo tem como objetivo demonstrar que na história social dos direitos humanos, na visão da concepção marxista, o estado nasce com a união dos senhores feudais com o rei (apenas a nobreza), contrariando a história tradicional que diz que os estados nacionais foram formados pela união do rei com a burguesia. Seguido para o momento em que toma o poder e acaba de vez com o feudalismo, nascendo, assim, as constituições como forma de assegurarem o estado burguês para o pleno desenvolvimento do capitalismo. Assim, como a concepção marxista defende que a história é uma luta de classes sociais (antagônicas), o Direito não seria nada mais do que uma forma material e legal de a classe dominante (burguesia) justificar seu domínio sobre a classe hierarquicamente inferior (proletariado).

PALAVRAS-CHAVE: Estado. Nação. Constitucionalismo.

\section{ABSTRACT}

This article aims to demonstrate that the social history of human rights in view of the Marxist conception, the state is born with the union of feudal lords to the king (only the nobility) contrary to the traditional story that says that the national states were formed by king's union with bourgeoisie. Followed to the time you take the power and just once with feudalism, born thus constitutions in order to ensure the bourgeois state to the full development of capitalism. Thus, as the Marxist theory holds that history is a social class struggle (antagonistic), the right would be nothing more than a physical and legal form of the ruling class (bourgeoisie) justify its hold on the hierarchically lower class (proletariat).

KEYWORDS: State. Nation. Constitutionalism. 


\section{INTRODUÇÃO}

O presente artigo tem como objetivo demonstrar que na história social dos direitos humanos, na visão da concepção marxista, o estado nasce com a união dos senhores feudais com o rei (apenas a nobreza), contrariando a história tradicional que diz que os estados nacionais foram formados pela união do rei com a burguesia. Seguido para o momento em que toma o poder e acaba de vez com o feudalismo, nascendo, assim, as constituições como forma de assegurarem o estado burguês para o pleno desenvolvimento do capitalismo. Assim, como a concepção marxista defende que a história é uma luta de classes sociais (antagônicas), o Direito não seria nada mais do que uma forma material e legal de a classe dominante (burguesia) justificar seu domínio sobre a classe hierarquicamente inferior (proletariado).

Para realização da presente investigação, foi necessário aplicar o método dogmático, como a hermenêutica dos textos normativos recomenda, mas também o aporte à doutrina e à transversalidade foi necessário, por se tratar de tema interdisciplinar de elevado teor político e sociológico, tudo alinhavado por uma tradição de pensamento racionalista da formação dos estados e surgimentos das constituições.

Assim, o artigo ora apresentado como trabalho de conclusão da disciplina teoria e crítica da cidadania, divide-se em quatro partes. Na primeira, realizouse uma demonstração sobre o surgimento dos estados nacionais, os interesses das classes sociais envolvidas, e um estudo sobre os doutrinadores e teóricos desses temas.

A segunda apresenta estudos sobre o momento em que a burguesia toma o poder, analisando-se o caso da Revolução Francesa.

A terceira trata do estudo da concepção marxista do Direito.

A quarta, e última parte, analisa o surgimento do constitucionalismo.

Por fim, a investigação em mãos representa um convite ao leitor interessado em saber mais sobre as reais possibilidades que o Estado, por meio do surgimento do constitucionalismo, apresenta de oportunidades para que as pessoas se desenvolvam com dignidade humana e justiça social.

\section{FORMAÇÃO DOS ESTADOSNACIONAIS}

A história tradicional diz que o rei, ao se aliar à burguesia nascente, conseguiu poderes que antes estavam dispersos nas mãos da nobreza feudal.

A nova história crítica diz que essa é uma tese falha que não merece 
prosperar, porque o Estado absolutista foi criado pela união dos nobres. Foram os senhores feudais que concordaram em concentrar toda autoridade nas mãos dos reis.

\section{I A monarquia absolutista}

No estado nacional absolutista, o rei tinha um poder absoluto. Isso quer dizer que as únicas leis que valiam eram as leis nacionais aprovadas pelo rei. $\bigcirc$ único tipo de moeda que podia circular em toda a nação era o que fosse autorizado pelo rei. Os comandantes do exército e da marinha, os ministros, todos eram nomeados pelo rei. (SCHMIDT, 1999).

A autoridade do rei era absoluta, porque não podia ser contestada. Sempre valia a vontade dele. Não existiam eleições nem partidos políticos, nem Constituição, nem mesmo um parlamento com deputados. Ninguém publicava um livro sem autorização real. Todos tinham de obedecer a ele. $\bigcirc$ monarca estava acima de todas as leis. (SCHMIDT, 1999).

Os primeiros estados nacionais da Europa tinham um regime político chamado monarquia absolutista. Monarquia porque tem um rei, absolutista porque o rei governa sem limites. (SCHMIDT, 1999).

Segundo José Damião de Lima (TRINDADE, 2002, p. 17), para explicar as razões do surgimento do estado nacional e da monarquia absolutista, é preciso entender como estava a Europa no final da idade média.

$\bigcirc$ fato de as pessoas falarem o mesmo idioma e partilharem as mesmas tradições culturais ajudava-as a se sentirem "da mesma família", "da mesma comunidade" e "da mesma nação". As rotas de comércio ligavam os interesses econômicos de muitas cidades e regiões e estimulavam a ideia de que, se todos se unissem, seriam mais fortes, mais protegidos contra os "estrangeiros". Mas não foi só por isso que se formaram os Estados nacionais. (SCHMIDT, 1999).

Conforme dizia Marx, a história é uma luta de classes; então, para entender por que surgiram os Estados nacionais é preciso estudar o que estava acontecendo com as classes sociais, como a nobreza feudal, a burguesia e os camponeses, no final da idade média.

José Damião de Lima (TRINDADE, 2002, p. 2 I) diz que primeiramente a Europa sofreu com a grande crise econômica do século XIV. A população havia crescido, passava fome e não havia mais terras disponíveis para plantar. Para piorar o quadro, as guerras e a peste negra mataram milhares de pessoas. As cidades diminuíram de tamanho, os campos foram abandonados. Com esse empobrecimento geral, os nobres recebiam tributos feudais cada vez menores, 
ou seja, até os nobres tinham sua riqueza diminuída.

Vendo suas rendas diminuírem, os nobres tomaram uma atitude brutal: aumentaram a exploração feudal sobre os servos. Exigiram mais e mais tributos. Mas a resposta dos servos também foi brutal e eclodiram inúmeras revoltas em muitas regiões da Europa. Os servos invadiam os castelos, pegavam os objetos de valor e incendiavam o que sobrava. Em muitos feudos, as terras foram tomadas pelos camponeses e divididas entre eles.'

Para José Damião de Lima (TRINDADE, 2002, p. 18), as revoltas dos servos eram tão maciças que o exército particular de cada senhor feudal já não era suficiente. Os nobres começaram a perceber que precisavam se unir para se defenderem das revoltas que ameaçavam todos os senhores feudais. Ficava claro que só haveria uma maneira de combater as rebeliões e salvar o feudalismo: a formação de um grande exército que atuasse em vastos territórios para esmagar de vez as revoltas servis. ${ }^{2}$

Para montar um exército, era preciso dinheiro e organização. Portanto, o Estado absolutista foi a organização que os nobres encontraram para se unir, cobrar impostos de tanta gente, manter a ordem feudal sobre vastos territórios, criar novas leis e nomear novos funcionários. (SCHMIDT, 1999).

O historiador inglês Perry Anderson destaca que:

Durante toda a fase inicial da época moderna, a classe dominante - econômica e politicamente - era, portanto, a mesma da época medieval: a aristocracia feudal. (...) Essencialmente, o absolutismo era apenas isso: um aparelho de dominação recolocado e reforçado, destinado a sujeitar as massas camponesas à sua posição tradicional. (...) Em outras palavras, o Estado absolutista nunca foi um árbitro entre a aristocracia e a burguesia, e menos ainda um instrumento da burguesia nascente contra a aristocracia: era a armadura política de uma nobreza atemorizada. (ANDERSON, 1985, p. 18)

\footnotetext{
'Segundo o historiador Francês Georges Duby (DUBY, 2009, p. 222), ele conhece uma carta de um nobre da época que, apavorado, escreveu contando que tinha ouvido boatos de que os servos haviam estuprado uma condessa na frente do marido. Depois, amarraram o conde e puseram no fogo nele. Em seguida, obrigaram a esposa comer pedaços da carne assada do cadáver do marido. É provável que essa história seja exagerada, mas de qualquer modo ela revela o pavor que os nobres estavam sentindo com as insurreições camponesas.

${ }^{2}$ Segundo o historiador Francês Georges Duby (DUBY, 2009, p. 238), a crise no século XIV e o aumento dos tributos feudais geraram revoltas populares. (Na França, a rebelião camponesa foi chamada de jacquerie. Na Inglaterra, foi liderada por um artesão chamado Watt Tyler e apoiada pelo padre John Ball). Os camponeses perguntavam: "Quando Adão cavava a terra e Eva fiava, onde estava o cavaleiro?". O estado absolutista nasceu para esmagar essas revoltas.
} 
Estado absolutista foi criado pela união dos nobres. Foram eles que concordaram em concentrar toda autoridade nas mãos dos reis. $\bigcirc$ Estado absolutista era uma superarma nas mãos dos senhores feudais. Antes, quando os servos se revoltavam, eles eram liquidados pelo próprio nobre e suas tropas. Com o Estado nacional, os nobres haviam construído uma superespada e um superescudo: o Estado absolutista. Se os servos ousassem se revoltar, teriam de enfrentar as leis do rei, os tribunais do rei, os exércitos do rei. (SCHMIDT, 1999).

Ainda com Perry Anderson (ANDERSON, 1985, p. 19), o Estado absolutista não era neutro em relação às classes sociais. O rei até que falava em governar "para todo o povo", mas, na prática, quando estourava uma revolta de camponeses contra nobres, o rei estava sempre de um lado: dos nobres e do feudalismo.

De qualquer modo, os reis não podiam fazer tudo o que quisessem. Se um rei "enlouquecesse" e tomasse partido dos servos contra os nobres, provavelmente os nobres se rebelariam e o substituiriam por outro monarca mais "lúcido". Isso mostra que as decisões do rei podiam ser limitadas pelos interesses da nobreza. (SCHMIDT, 1999).

\section{I.2 Os interesses da burguesia}

Para José Damião de Lima (TRINDADE, 2002, p. 24), a unificação nacional favorecia a burguesia. A razão era simples: os monarcas absolutistas davam força para os negócios da burguesia. Por exemplo, faziam leis que proibiam importação de produtos estrangeiros concorrentes dos produtos da burguesia nacional. E os reis protegiam os negócios da burguesia porque quanto mais dinheiro a burguesia ganhasse, mais impostos poderiam pagar ao Estado. Uma mão lavava a outra.

Não foi à toa que grandes comerciantes e banqueiros emprestaram dinheiro e deram todo apoio aos monarcas e nobres que lutavam pelo reforço do poder real. Afinal, todos ganhavam com isso. (SCHMIDT, 1999).

Segundo José Damião de Lima (TRINDADE, 2002, p. 26), o Estado absolutista podia ser interessante tanto para a nobreza como para a burguesia. Ele ajudava a conciliar os interesses das duas classes sociais, ou seja, o rei e seus auxiliares se empenhavam em harmonizar a burguesia com a nobreza, levando as duas a obterem vantagens. 
O historiador brasileiro Francisco J. C. Falcon

Esse tipo de Estado assegura à aristocracia a manutenção de sua hegemonia.
[Liderança] (...) [Mas também é verdade que] a burquesia mercantil encontrou
na aliança com os príncipes [os monarcas] um instrumento capaz de favorecer
seus próprios interesses econômicos e políticos. (...) Mas, afinal, esse Estado é
feudal ou é capitalista? Na verdade, diríamos que ele é as duas coisas e, por isso
mesmo, não é exatamente nem uma, nem outra. (...) O Estado absolutista tende
a expressar a busca de um equilíbrio precário, a longo prazo impossível, entre
classes (...) cujos interesses são em parte complementares e em parte
antagônicos. (FALCON, 1986, p. 32-36.)

No entanto, não dá para se enganar: o Estado absolutista era um Estado feudal. A principal finalidade de sua existência era salvar a pele do feudalismo das revoltas servis e dos avanços econômicos da burguesia. Dois aspectos mostram isso muito bem. Primeiro: os burgueses pagavam altos impostos ao Estado, a nobreza não. Segundo: os principais cargos da burocracia estatal (funcionários públicos) eram reservados aos nobres. Apenas membros das tradicionais famílias nobres é que podiam se tornar ministros, governadores, diplomatas, almirantes e generais. No Estado absolutista, a lei não era a mesma para todos. As famílias de "sangue azul" (da nobreza) tinham privilégios especiais garantidos pela lei. (SCHMIDT, 1999).

\section{I.3 O grande pensador da cidadania}

Mais conhecido como Marsílio de Pádua, esse escrito veio a se tornar conhecido a partir do escrito Defensor Pacis (O Defensor da Paz). Nessa obra, ele criou teoria própria sobre os diversos conflitos que traziam insegurança ao mundo ocidental, e, estudando o envolvimento no conflito entre poder religioso e civil, ele propôs uma resolução ao problema. (STREFLING, 20 I 0, p. 154).

Essa obra é composta em três partes, sendo que a primeira trata dos temas fundamentais, iniciado com um tratado sobre a paz, o surgimento e o significado da existência da civitas; defende que a lei seja o fundamento do estado, e que o clero, igual às outras partes, seja um órgão do estado. (STREFLING, 20 I0, p. 154).

Com argumentos filosóficos e usando parcialmente Aristóteles, Marsílio de Pádua elaborou uma teoria sobre o que é e o que deveria ser um estado. (STREFLING, 2002, p. II5).

Marsílio de Pádua também elaborou uma concepção de paz na civitas, 
baseado em Platão e Aristóteles; além da influência na fé cristã, o filosofo paduano defendeu que a paz é essencialmente composta pela justiça, a paz não é apenas um bem-estar ou uma prosperidade, porque sem a justiça não existe a paz. (STREFLING, 20 I 0, p. I55).

As revoluções acontecem nas sociedades civis devido ao seu crescimento desproporcional. De fato, como o corpo se compõe de várias partes que devem se desenvolver proporcionalmente, de forma que a harmonia subsista se o corpo se desenvolver diferentemente, não só em qualidade, mas também em quantidade, o organismo será prejudicado. Sendo igualmente a cidade constituída por grupos sociais, se um deles se ampliar mais do que os outros, sem o percebermos, tal como acontece com os pobres nas democracias, então acontecerão as revoluções. (MARSILIUS VON PADUA, Defensor Pacis, I, I5, 10).

Para Marsílio, a cidade precisa de um poder coercitivo, e esse poder é assegurado pela lei; caso não exista esse poder, as associações dos cidadãos sempre terão conflitos, e caso não esteja regulamentado pelas normas, surgirão guerras que poderão destruir as cidades. Por isso é que a lei é essa norma que garante o que é justo e institui um guardião ou executor facilitando a convivência social. (STREFLING, 20 I0, p. 160).

\section{I.4 O grande pensador político renascentista do cinquecento}

Segundo Marilena Chaui (CHAUI, 2002, p. 200), o mais célebre pensador que analisou os conceitos de estado nacional, soberania etc. foi o italiano Nicolau Maquiavel, sério estudioso da história, que procurou extrair lições úteis para sua época. Só por exemplo, foi investigando a Roma antiga que ele concluiu que a unidade nacional é fundamental para a grandeza de um povo. Mas talvez a verdade seja que Maquiavel se preocupava com sua querida Itália, a qual não conseguia formar seu estado nacional.

Ainda com Marilena Chaui (CHAUI, 2002, p. 202), a vida política italiana do tempo de Maquiavel tinha se tornado um vale-tudo pelo poder. Nobres e burgueses contratavam mercenários para ajudá-los a se tornarem governantes das cidades-estados. A corrupção e o assassinato político eram coisas normais. Maquiavel concluiu que, num mundo assim, era preciso abandonar a ideia medieval de que as ações humanas precisavam acompanhar a moral cristã. Os homens não vivem no Céu ideal, mas na Terra real, dizia Maquiavel. E na terra (na Itália da época) ninguém chega ao poder por ser bonzinho. O poder é alcançado pelo homem que tem a virtude de combinar a audácia com a 
capacidade de agir no momento certo, a ousadia com a sorte. Somente um líder assim seria capaz de fundar o estado italiano. A famosa obra de Maquiavel, 0 Príncipe, é um manual para ensinar esse homem destemido a unificar o país.

As ideias de Maquiavel podiam ser brilhantes, mas a sociedade italiana reunia muitos conflitos que impediam que houvesse a unificação. Com isso, o pensador morreu muito antes de os italianos construírem seu estado nacional, que só aconteceu no final do século XIX. (SCHMIDT, 1999).

\section{I.5 Liberalismo Político-As ideias revolucionárias}

Durante o século XVII, surgiram as ideias que despertaram a consciência política para os ingleses fazerem a revolução gloriosa. Os dois pensadores mais destacados da época foram Thomas Hobes e John Locke. (SCHMIDT, 1999).

Marilena Chaui (CHAUI, 2002, p. 208) diz que Hobbes viveu durante a guerra civil e a ditadura de Cromwell e ficou impressionado com a tragédia de ingleses matando ingleses. Na sua obra, O Leviatã, o pensador indaga: como evitar que o homem seja o lobo do homem? Sua resposta: todos devem concordar em se submeter à autoridade do Estado. Para ele, um Estado forte impediria que os conflitos sociais destruíssem a sociedade.

Segundo o historiador Francês Georges Duby (DUBY, 2009, p. 286) em 1688, a Revolução Gloriosa coroou Guilherme de Orange, rei da Inglaterra. $\bigcirc$ mesmo navio que transportou o príncipe Guilherme de Holanda para a Inglaterra também levou o filósofo John Locke. A revolução burguesa na Inglaterra consagrou as ideias do liberalismo político de Locke. Na sua famosa obra, o grande pensador destaca:

(...) Ninguém pode ser expulso de sua propriedade e submetido ao poder político de outra pessoa sem dar consentimento. (...) $\bigcirc$ grande objetivo da União dos homens em comunidades, submetidos a um governo, é a preservação da propriedade. (...)

Não possuem autoridade o homem ou vários que passarem a fazer lei sem que o povo os tenha escolhido para essa tarefa. Então, o povo não está obrigado a obedecer (...).

Sempre que os legisladores [o governo] tentam tirar e destruir a propriedade do povo, ou reduzi-lo à escravidão sob poder arbitrário,o povo pode entrar em guerra contra o governo. (...)

Quem julgará se o governo age contrariamente ao encargo recebido? (...) A isso respondo: o povo será o juiz. (LOCKE, John. Two treatises of civil government [Dois tratados sobre o governo civil]. 2a Ed. Cambridge: Cambridge University Press, 197I. Adaptado.) 
Locke também concordava com a ideia de que o Estado deveria ser organizado a partir do consenso (do acordo entre os cidadãos). Mas ele rejeitava a submissão total do indivíduo ao Estado. O constitucionalismo começa a ganhar força a partir das citações de Locke. (BOBBIO, 20 I 0, p. 248).

No seu famoso livro, Segundo Tratado Sobre o Governo Civil, ele diz que o Estado não existe por vontade de Deus (como gostavam de afirmar os monarcas absolutistas), mas que tinha sido construído pelos homens a partir de um contrato. $O$ Estado havia nascido para proteger a vida, a liberdade e a propriedade dos indivíduos. Acontece que existem Estados que não cumprem suas funções. Tendo outros que atacam a propriedade dos indivíduos, ameaçam sua liberdade e sua vida, Locke acusava o Estado absolutista de opressor. (SCHMIDT, 1999).

Como o Estado tinha sido criado por um acordo entre os homens, então os indivíduos tinham o direito de mudar o governo.

Locke é considerado um dos pais do liberalismo político. $O$ nome "liberalismo" tem a ver com a liberdade. Para os liberais, o Estado não pode sufocar as liberdades individuais. Ou seja, cada pessoa tem o direito de escolher suas próprias ideias religiosas, políticas ou filosóficas, de falar em público e de escrever livros e artigos de jornais defendendo suas convicções (liberdade de expressão), de viajar para onde quiser, de escolher a profissão que desejar. (SCHMIDT, 1999).

Uma coisa muito importante: os liberais acreditam que o direito à propriedade é a garantia da liberdade individual. Assim, um homem só é realmente livre quando possui uma propriedade e faz dela o que bem entende. Entretanto, a liberdade do indivíduo tem um limite: não pode sufocar a liberdade de outro indivíduo. É a ideia de que a minha liberdade termina onde começa a sua, e vice-versa. Por isso, deve existir uma lei, aprovada pela maioria dos cidadãos, que impede que um indivíduo prejudique a liberdade do outro. Portanto, a liberdade significa o respeito à lei democrática. (SCHMIDT, 1999).

\section{I.6 O lluminismo - os pensadores da revolução}

A revolução gloriosa inglesa impressionou os europeus, as ideias filosóficas de John Locke também entusiasmavam os intelectuais franceses.

Isso serviu de base para um grupo de pensadores que receberam o nome de lluministas.

As ideias iluministas tiveram muita força na independência dos EUA e na Revolução Francesa. Até mesmo os latino-americanos nos seus movimentos de 
independência foram influenciados.

\section{I.6.I Rosseau}

Segundo Dalmo Dallari (DALLARI, 2005, p. I 45), Rousseau foi talvez o mais democrata de todos os iluministas. A maioria dos iluministas era a favor do despotismo esclarecido. Rousseau preferia um governo de assembleias populares. Para ele, só poderia haver direitos de cidadania quando as pessoas participassem das decisões do governo. Na sua obra, O Contrato Social, mostrou que os governos foram criados por vontade dos cidadãos e, portanto, os cidadãos tinham o direito de mudá-los.

\section{I.6.2 Montesquieu: a separação dos poderes}

Segundo Paulo Bonavides (BONAVIDES, 1997, p. 137), Montesquieu foi um dos criadores da teoria da separação dos três poderes para controlar os poderes absolutos do rei. Desse modo, o poder seria limitado pelo próprio poder. Montesquieu era nobre, mas de certa forma contrariou os interesses da nobreza. O que mostra que nem sempre uma pessoa raciocina de acordo com os interesses da classe social a que pertence.

Montesquieu apud Giuseppe de Vergottini:

Tudo estaria perdido se uma só pessoa, ou um só corpo de notáveis, de nobres ou de povo, exercesse estes três poderes: o de fazer as leis, o de executar as decisões públicas e o de punir os delitos ou contendas entre os particulares. (BOBBIO, 2010, p. 248).

Pela teoria dos três poderes, o governo deveria ser repartido entre pessoas diferentes. O poder Executivo (que administra o país) deveria ser entregue ao rei (monarquia) ou a uma pessoa eleita para isso (democracia). $\bigcirc$ poder Legislativo (que faz as leis e fiscaliza o Executivo) deveria estar nas mãos de uma assembleia de deputados eleitos pelos cidadãos. O Poder Judiciário (que garante o cumprimento das leis) seria exercido por juízes e tribunais. (SCHMIDT, 1999).

Giuseppe de Vergottini destaca que a experiência constitucional da Inglaterra, embora tenha sido na idade moderna, se pareceu com motivos medievais. "Na realidade, a separação dos poderes foi ideada e articulada para uma sociedade ainda aristocrática, com um regime político monárquico". (BOBBIO, 2010 , p. 252). 
Montesquieu foi um dos idealizadores do constitucionalismo, porém um constitucionalismo limitado à separação dos poderes, imperfeitamente sob o aspecto histórico, tendo em vista que compreende somente um dos lados, o estado misto, enfatizando sua versão mais moderna, a separação dos poderes. (BOBBIO, 20। 0, p. 253).

\section{ABURGUESIA TOMA O PODER}

Para Manuel Gonçalves (FERREIRA FILHO, 2004, p. 19), um dos primeiros passos da Revolução Francesa foi a abolição dos privilégios.

Os privilégios de diversas formas favoreciam o segundo estado (a nobreza) e o primeiro estado (o clero), portanto, eram as classes privilegiadas em relação ao povo; a partir daí começa a surgir o princípio da igualdade ou isonomia. (SCHMIDT, 1999).

Camponeses e Sans-Cullotes passavam muita necessidade, por conta dos altos impostos pagos para sustentar a riqueza da nobreza.

Jacques Revel destaca que:

A crítica denota uma série de círculos de exclusões: os estrangeiros com relação aos franceses; os plebeus, os provincianos e os pedantes com relação a uma aristocracia que em tal ocasião redescobre a irredutível vantagem proporcionada pelo dom do nascimento: todos tem algo de menos com relação aos eleitos, e a civilidade é sua marca vulgar. Ante o perigo que representa um eventual nivelamento das condutas sob a norma comum, o estilo - a liberdade das aparências emancipadas de toda autoridade - volta a ser o árbitro do verdadeiro decoro. A isso Mercier acrescenta pouca coisa, quase um século depois. Embora burguês, teve o cuidado de excluir o "pequeno-burguês" do círculo daqueles "que tem o trato social” (CHARTIER, 2009, p. 204).

Francisco J. C. Falcon (FALCON, 1986, p. 63-67) diz que a maioria dos burgueses, por sua vez, também não estava satisfeita, pagava ao governo impostos tão altos que dispunha de pouco capital para investir. Além disso, o governo utilizava o dinheiro dos impostos para sustentar o luxo da nobreza. Os burgueses preferiam que o Estado empregasse o dinheiro no incentivo ao crescimento dos negócios, como na abertura de estradas e na melhoria dos portos. Mas o Estado Francês muitas vezes prejudicava as atividades da burguesia. Em 1786, por exemplo, o rei autorizou que os tecidos ingleses fossem vendidos livremente na França, concorrendo com os franceses.

Manuel Gonçalves (FERREIRA FILHO, 2004, p. 2I) fala de quando a assembleia aprovou a célebre Declaração dos Direitos do Homem e do 
Cidadão. Esse documento baseava-se nas ideias iluministas. Para os revolucionários, só haveria justiça se esses direitos fossem garantidos. E quais eram esses direitos? A Declaração afirmava que todos os homens nascem livres e iguais e, portanto, ninguém pode ser escravo nem servo; ninguém pode ser preso por causa de opiniões políticas ou religiosas; a lei tem de ser a mesma para todos; a justiça tem de ser gratuita; ninguém pode ser torturado; os acusados possuem direito a um advogado e devem ser julgados em público; todos os cidadãos que tenham capacidade podem ocupar cargos no governo; o governo só pode tomar decisões que estiverem de acordo com a vontade geral da população. Mais ainda, o povo tem o direito de resistir à opressão.

Manuel Gonçalves (FERREIRA FILHO, 2004, p. 22) diz que, em I79I, a Constituição estava pronta. Ela tomava por base a Declaração dos Direitos do Homem e do Cidadão. Estabeleceu a igualdade civil (a lei passava a ser a mesma para todos) e a separação dos três poderes (a ideia do iluminista Montesquieu): o Poder Executivo continuava com o rei, mas o Poder Legislativo seria exercido por uma assembleia de deputados. $\bigcirc$ absolutismo tinha acabado. $\bigcirc$ rei ainda era o mesmo, Luís XVI, mas agora ele tinha de obedecer às leis feitas pelos deputados. A França havia se tornado uma monarquia constitucional.

No regime absolutista, não existe nenhuma Constituição, portanto, a criação de uma constituição significava a destruição do regime absolutista. Ou seja, era a própria revolução acontecendo! (SCHMIDT, 1999).

Na concepção marxista, a história é feita por uma luta de classes sociais antagônicas, a Constituição passa a ser a forma material e legal de a nova classe dominante (burguesia) justificar seu domínio sobre os dominados (proletariado).

A partir daquele momento, os proprietários de terras também tinham de pagar impostos. Os bens da Igreja (terras, tesouros, prédios) foram confiscados pelo Estado. (SCHMIDT, 1999).

Para Nestor Sampaio (PENTEADO FILHO, 20 I I , p. 44), a revolução tinha sido feita pelo Terceiro Estado. Os burgueses, os sans-culottes, a pequena burguesia e os camponeses tinham se rebelado em conjunto. Mudanças formidáveis aconteceram em favor de todos. Mas a burguesia tinha sido a principal beneficiada. A Declaração dos Direitos do Homem e do Cidadão dizia que a propriedade privada era inviolável. Ou seja, ninguém tinha o direito de tocar nas riquezas da burguesia. A assembleia também aprovou leis que extinguiam os monopólios mercantilistas, estabelecendo a liberdade para o mercado.

Segundo Francisco J. C. Falcon (FALCON, 1986, p. 63-67), as camadas 
populares se sentiam prejudicadas. Os camponeses, por exemplo, continuavam sem terra. Quando o Estado vendeu as terras da Igreja, os beneficiados foram os ricos burgueses. Os deputados eram eleitos com sufrágio censitário, somente as pessoas com certo nível de renda podiam votar. $\mathrm{Na}$ prática, cerca da metade dos franceses estava de fora. Para piorar, a Assembleia aprovou a Lei de Le Chapelier, que proibia os trabalhadores de formarem associações para defender seus direitos.

Os camponeses e os sans-culottes exigiam mudanças. Tinham o apoio dos deputados radicais da pequena burguesia. Um deles, o advogado Robespierre, ${ }^{3}$ segundo o historiador Francês Georges Duby (DUBY, 2009, p. 479), era defensor do fim da escravidão nas colônias e do direito das mulheres ao voto, fez um discurso inflamado em que perguntava aos representantes da alta burguesia: "Quem os autorizou a despojar o povo de seus direitos?".

Robespierre era do partido jacobino (pequena burguesia), também chamado de montanha. Os jacobinos também eram a favor da propriedade privada, mas chegaram a declarar que o direito do bem-estar social era mais importante que o direito à propriedade. Defendiam que o Estado deveria exercer algum controle sobre a economia. (SCHMIDT, 1999).

Para alguns escritores, os jacobinos eram demagogos, para outros eram democratas.

Aristóteles, apud Giampaolo Zucchini, destaca a demagogia da seguinte forma:

Quando, porém, nos governos populares a lei está subordinada ao arbítrio de muitos, surgem os demagogos, que abrandando e adulando as massas, exasperando seus sentimentos destruidores, distraindo-as do seu compromisso político, acabam indicando os opositores do regime despótico instaurado como inimigos do povo e da pátria. Conseguem assim consolidar o próprio poder com a eliminação de toda e qualquer oposição. Aristóteles define, portanto, o demagogo com um "adulador do povo" (Politica, v, II, | 313 b)(...)eliminando toda a oposição. Nestas condições, os demagogos arrogam-se o direito de interpretar os interesses das massas, chamando a si todo o poder e a

${ }^{3}$ Foi o principal líder jacobino. Famoso por sua firmeza, tinha o apelido de "o Incorruptível". Quando se tornou o homem mais poderoso da França, continuou morando na mesma casa, comendo as mesmas refeições moderadas, vestindo as mesmas roupas. Implacável com os inimigos políticos (enviou centenas à guilhotina), defensor dos direitos dos pobres, das mulheres e dos judeus. Não tolerava nenhuma oposição política, pois considerava que ela só servia para atrapalhar "o verdadeiro rumo da revolução".

Essa intolerância com a oposição acabaria destruindo os jacobinos e também muitas outras revoluções. (DUBY, 2009, p. 456) 
representação das massas, instaurando uma tirania ou ditadura pessoal. (BOBBIO, 2000, p. 318-319).

Norberto Bobbio, ao tratar da democracia, cita Saint Just e Robespierre ao defender que a nova democracia irá varrer, para sempre, o déspota ou o tirano, porque será o governo da virtude. Robespierre discursou que "a mola do governo popular na revolução é, a um tempo, a virtude e o terror, sem a virtude, o terror é funesto: a virtude sem o terror, é imponente". (BOBBIO, 2000, p. 323).

Norberto Bobbio, apud Platão na República da Democracia, diz que:

Nasce quando os pobres, após haverem conquistado a vitoria, matam alguns adversarios, mandam outros para o exílio e dividem com os remanescentes, em condições paritárias, o Governo e os cargos públicos, sendo estes determinados, na maioria das vezes, pelo sorteio.(557a) (BOBBIO, 2000, p. 320).

Giuseppe de Vergottini interpreta as ideias jacobinas sustentando que elas garantem a vontade geral e merecem ser defendidas no plano constitucional: os direitos fundamentais do homem, a liberdade de ir e vir, a liberdade de declarações na imprensa, defesa dos credos religiosos, e a propriedade privada para a burguesia. Dessa forma, se o cidadão obedece ao estado, ele está obedecendo a si mesmo, porque isso vem da "mística da vontade geral que nos vem da tradição jacobina francesa” (BOBBIO, 2000, p. 250-257).

\footnotetext{
${ }^{4}$ Napoleão e o mito do herói: observando a força do acaso, alguns historiadores comentam que quando era estudante, Napoleão se inscreveu num concurso que dava como prêmio uma viagem de pesquisa científica. Mas foi reprovado, só que os estudantes que venceram morreram quando o navio em que viajavam naufragou no oceano pać́fico. Esses historiadores usam essa história verdadeira, para demonstrar que se Napoleão tivesse morrido, a burguesia francesa teria encontrado outro general para ser coroado Imperador, porque a história não é feito por heróis, a história não é feita só por uma pessoa, tudo o que acontece é o resultado das ideias e das ações de todas as pessoas. Também não podemos ignorar as ações das classes sociais lutando por seus interesses. Sem o apoio da burguesia Napoleão nunca teria chegado ao poder. (DUBY, 2009, p. 554) Como dizia Karl Marx, a história é uma luta de classes. Os iluministas tinham um grande sonho. Eles acreditavam que um dia todos os homens e mulheres aprenderiam a refletir criticamente. Então, todos os indivíduos pensariam por conta própria e não aceitariam mais se submeter a alguém. A humanidade entraria numa nova era de autoconfiança, liberdade e felicidade.
} 
A revolução burguesa se consolida quando os políticos astutos do Diretório perceberam que o general Napoleão Bonaparte ${ }^{4}$ era o homem certo para consolidar o novo regime. Propuseram a ele que utilizasse a força do exército para assumir o governo. Foi o golpe do 18 Brumário ( I799); durante esse período, a burguesia consolidaria seu domínio econômico. (SCHMIDT, 1999).

Segundo o historiador Francês Georges Duby (DUBY, 2009, p. 54I), o general Napoleão gostava de dizer que sua maior obra não tinha sido as mais de 40 batalhas vitoriosas, mas o famoso Código Civil ( I 804). Esse código era um conjunto de leis as quais determinavam quais eram os direitos de quem possuía uma propriedade. Ao mesmo tempo, proibia que os trabalhadores tivessem suas próprias associações. As conquistas da burguesia postas na letra da lei!

Nesse mesmo ano, Napoleão torna-se imperador, com apoio popular, como muitas vezes acontece no começo das ditaduras, imperador burguês, mas imperador. (SCHMIDT, 1999).

\section{O DIREITO NA CONCEPÇÃO MARXISTA}

O conceito de direito em Marx pode ser resumido como o aspecto legal e material em que a classe dominante (burguesia) usa o poder para justificar sua dominação ou seu domínio sobre a classe inferiormente hierárquica (proletariado), antagonismos das classes sociais.

Para István Mêszáros, ${ }^{5}$ o velho Marx, após ter elaborado a sua concepção materialista da história, desenvolveu a tese de que o direito era essencialmente dependente da superestrutura, ou seja, Marx percebe ao afirmar que o Direito era um reflexo das concepções, das necessidades e, ainda, dos interesses de uma classe dominante, esta produzida pelo desenvolvimento das forças produtivas e das relações de produção que constituem a base econômica do desenvolvimento social.

Segundo Paulo Nader (NADER, 2000, p. 231), ao produzir esta teoria de

\footnotetext{
${ }^{5}$ Texto apresentado na Conferência de Dublin, realizada entre 30 de novembro e 4 de dezembro de 1978, por ocasião do $30^{\circ}$ aniversario da Declaração dos Direitos Humanos das Nações Unidas. Versão resumida foi publicada em A. D. Falcomer (Ed.) Understandig human rights (Dublin, Irish Shool of Ecumenies, 1980, p. 47-6I)
} 
que o Direito é uma forma de dominação de classe Marx, na realidade trata esse sistema de conceito como um conjunto de mandamentos sancionados pelo Estado.

Roberto Lyra (FILHO, 199, p. 23) percebe que quando Marx, ao referir-se com palavras como "apropriação" e "propriedade", está se referindo a fatos infrajurídicos, embora deixe levantada a questão de que o Direito deve ser necessário para assegurar o poder conquistado sem ele, ou antes, dele.

A finalidade do Estado é garantir o interesse comum, mas este é concebido como o conjunto dos interesses dos indivíduos proprietários. Assim, o Estado é caracterizado por Marx como "comunidade ilusória".

Norberto Bobbio diz que a essência do socialismo sempre foi a revolução, a democracia direta seria o pedido popular de participação no governo e a reivindicação de controle de poder de baixo para cima, controlando os órgãos de decisão político-econômica. Passando de autogoverno para autogestão, em que os chamados conselhos operários exercem o poder de controle da democracia econômica industrial (BOBBIO, 2000, p. 324).

Norberto Bobbio, apud Lenin, diferencia a democracia dos conselhos da democracia parlamentar, defendendo que na sociedade capitalista existe uma concentração da fiscalização dos órgãos pelas grandes empresas, e que o cidadão fica sem poder para abolir os privilégios que prejudicam a vida em sociedade. (BOBBIO, 2000, p. 325).

Norberto Bobbio, apud Mosca, diz que não existe outra forma de governo diferente da aristocracia, porque em toda a história do homem na terra o poder esteve concentrado nas mãos das minorias. (BOBBIO, 2000, p. 325).

Norberto Bobbio, apud Arend Lijphart, explica que o comportamento das elites fica mais próximo das coligações para tornar-se mais forte. (BOBBIO, 2000, p. 328).

\section{CONSTITUCIONALISMO}

É fato que a constituição é o instrumento da soberania do povo organizado em uma estrutura de poder designada para ser exercida por diversos órgãos.

A função do constitucionalismo é indicar as bases filosóficas para acompanhar os princípios internos das constituições. Giuseppe de Vergottini diz que o constitucionalismo "é a técnica da liberdade, isto é, a técnica jurídica pela qual é assegurado aos cidadãos o exercício dos seus direitos individuais e, ao mesmo tempo, coloca o Estado em condições de não os poder violar". (BOBBIO, 2000, p. 247-248). 
O constitucionalismo é também conhecido como governo das leis, e não das gentes, da razão no direito, e não apensa do poder; com diversas manifestações na história para a limitação do poder. Por isso, antes de aceitar o termo constitucionalismo, temos de aceitar o valor que intrinsecamente está relacionado na história do individualismo, do direito do homem como cidadão. (BOBBIO, 2000, p. 248).

Giuseppe de Vergottini diz que Kant idealizou uma nova versão da separação dos poderes, reproduzida pela Constituição Francesa, de I79 I, e que essa nova versão separa radicalmente as funções de executar e legislar, e que, nas constituições francesas seguintes às da revolução, um poder acabou por destruir o outro, "ou serviu apenas, como escreveu Kelsen, para "reservar ainda ao monarca, reduzido à metade da sua autoridade pelo movimento democrático, a possibilidade de exercer sua influência no campo executivo" (BOBBIO, 2000, p. 249).

No âmbito do conceito de estado, o constitucionalismo não tem como se desenvolver.

Uma nova definição de constitucionalismo, não muito frequente na nossa literatura política, baseada nas contraposições entre poder e direito, força e racionalidade, partindo de uma real diferença entre governo e constituição. A constituição é superior e anterior ao governo, por isso, limita o poder do governo, e caso a constituição seja violada, esse governo será inconstitucional. (BOBBIO, 2000, p. 256).

\section{CONSIDERAÇÕES FINAIS}

Pelo estudo do presente artigo, conclui-se que a história pode ser feita de maneira equivocada, ou melhor, a interpretação histórica pode ser feita preconceituosamente em relação a quem a vir, subestimando uma classe social que possa ter tido valor preponderante na relação.

A história nada mais é do que uma luta de classes antagônicas disputando o poder, sendo assim, falar que os estados nacionais foram formados pela união de rei mais a burguesia, chegaria a se dizer o quê? Que necessidade teria a burguesia em disputar com os camponeses e proletariados o controle do estado? É errônea aquela interpretação de que não merece prosperar mais pelos historiadores tradicionais, a nova história crítica comprova que a formação dos estados nacionais foi feita pela união dos nobres (rei mais senhores feudais), 


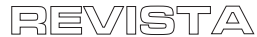

e as revoluções burguesas, com o nascimento da constituição foi o momento em que o estado virou burguês, para poder justificar o poder da classe dominante (burguesia) sobre os dominados (proletariado).

\section{REFERÊNCIAS}

ANDERSON, Perry. Linhagens do Estado absolutista. São Paulo: Brasiliense, 1985.

BOBBIO, Norberto; MATTEUCI, Nicola e PASQUINO, Gianfranco. Dicionário de política. Tradução Carmem c. Varriale... [et. al.]; coordenação da tradução João Ferreira; revisão geral João Ferreira e Luis Guerreiro Pinto Cascais. $5^{a}$ ed. - Brasília: Editora Universidade de Brasília. São Paulo: Imprensa Oficial do Estado de São Paulo, 2000.

BONAVIDES, Paulo. Ciência política. I0ª ed. São Paulo: Malheiros, 1997.

CHARTIER, Roger (org.). História da vida privada, 3: da renascença ao século das luzes. Tradução Hildegard Feist. - São Paulo: companhia das Letras, 2009.

CHAUI, Marilena. Convite a filosofia. São Paulo: Ática, 2002.

DALLARI, Dalmo de Abreu. Elementos de teoria geral do estado. São Paulo: Saraiva, 2005.

DUBY, Georges. História da vida privada, 3: da Renascença ao Século das Luzes / organização Roger Chartier. Tradução: Hildegard Feist. São Paulo: Companhia das Letras, 2009.

FALCON, Francisco J. C. Mercantilismo e transição. 7. ed. São Paulo: Brasiliense, 1986.

FERREIRA FILHO, Manoel Gonçalves. Direitos humanos fundamentais. 6. ed. São Paulo: Saraiva, 2004.

FILHO, Roberto Lyra. O que é direito. São Paulo: Brasiliense, 1999. 
LOCKE, John. Two treatises of civil government [Dois tratados sobre o governo civil]. $2^{a}$ Ed. Cambridge: Cambridge University Press, 197I . Adaptado.

MARSILIUS VON PADUA. O defensor da paz. Tradução de José Antonio C. R. Souza. Petrópolis: Vozes. 1997.

MÊSZÁROS, István. Texto apresentado na Conferencia de Dublin, realizada entre 30 de novembro e 4 de dezembro de 1978, por ocasião do 30 aniversario da Declaração dos Direitos Humanos das Nações Unidas. Versão resumida foi publicada em A. D. Falcomer (Ed.) Understandig human rights (Dublin, Irish Shool of Ecumenies, 1980, p. 47-6I).

NADER, Paulo. Filosofia do direito. Rio de Janeiro: Forense, 2000.

PENTEADO FILHO, Nestor Sampaio. Direitos humanos. $2^{\mathrm{a}}$ ed. São Paulo: Saraiva, $201 \mathrm{l}$.

SCHMIDT, Mario Furley. Nova historia crítica. São Paulo: Geração, 1999.

STREFLING, S. R. Igreja e poder. Plenitude do poder e soberania popular em Marsílio de Pádua. Porto Alegre: EDIPUCRS, 2002.

. A concepção de paz na civitas de Marsílio de Pádua. v. 32, n², p. |53-|6|. Maringá: EDIPUCPR, 2010.

TRINDADE, José Damião de Lima. História social dos direitos humanos. São Paulo: Petrópolis, 2002.

Recebido em: 28/06/2015

Aprovado em: 12/08/2015 